\title{
M
}

\section{Trade with the EU, Variable Geometry and Human Rights in the EAC}

\author{
ALEYDis NisSEN \\ FWO and F.R.S.-FNRS Postdoctoral Fellow \\ Leiden University, VUB, ULB \\ a.m.h.nissen@law.leidenuniv.nl
}

\section{ABSTRACT}

The Economic Partnership Agreement between the East African Community (EAC) and the European Union (EU) is of particular importance for the Kenyan floriculture sector. While the other EAC Partner States remain reluctant to ratify this agreement, they allowed the Republic of Kenya to start its implementation under the principle of variable geometry in June 2021. Kenya and the EU then started a strategic dialogue in which they pledged to strengthen their cooperation on human rights issues. This article identifies two priorities for floriculture workers: Kenya's ratification of the core labour rights Convention No. 87 on the Freedom of Association and Protection of the Right to Organise and the broadening of an enabling space for an active, organised and transparent civil society. 
AlEYDIS NisSEN, Trade with the EU, Variable Geometry and Human Rights in the EAC

Keywords: Kenya; Freedom of Association; Flowers; COTU-K; post-Cotonou

This paper has been subjected to double-blind peer review 


\section{Trade with the EU, Variable Geometry and Human Rights in the EAC}

SUMMARY: 1. Introduction. - 2. Trade relations between EAC and EU. - 3. Obligations relevant for floriculture workers. - 4. Priorities. 5. Conclusion.

\section{Introduction}

Benjamin William Mkapa, the former President of Tanzania and a fierce critic of the economic partnership agreement (EPA) between the EAC and the EU, alleged that the Kenyan floriculture sector pressured Kenya's President Uhuru Kenyatta to allocate considerable resources to the negotiation process of this agreement. ${ }^{1}$ These concerns were echoed in a briefing commissioned by the European Parliament. ${ }^{2}$ The floriculture sector - a vital organ of the Kenyan economy - needed to maintain preferential market access to the EU to guarantee its competitiveness. It is the fourth largest exporter of cut flowers in the world after the Dutch, Colombian and Ecuadorian floriculture sectors. ${ }^{3}$ This sector is exportdriven, with almost all produced flowers being air-transported to the EU. ${ }^{4}$ Two-

\footnotetext{
${ }^{1}$ Economic Partnership Agreement between the East African Community Partner States, of the one Part, and the European Union and its Member States of the Other Part (2014) <http://trade.ec.europa.eu/doclib/docs/2015/october/tradoc_153845.pdf> accessed 28 February 2020 (hereafter: EAC-EU EPA); Benjamin William Mkapa, 'Why the EPA is not Beneficial to Tanzania' (The South Bulletin, 1 November 2016) $<w w w . s o u t h c e n t r e . i n t / q u e s t i o n / w h y-t h e-e p a-i s-n o t-b e n e f i c i a l-t o-t a n z a n i a />$ accessed 28 February 2020.

2 Eric Pichon, 'Briefing. International Agreements in Progress. Economic Partnership Agreement with the East African Community' (2018) $<$ www.europarl.europa.eu/RegData/etudes/BRIE/2018/620218/EPRS_BRI(2018)620218_E N.pdf $>$ accessed 28 February 2020 p 9.

${ }^{3}$ David Whitehouse, 'Kenya's Flower Growers to Share Brexit Pain' The Africa Report (Paris, 17 April 2019) <www.theafricareport.com/11976/kenyas-flower-growers-to-sharebrexit-pain/> accessed 20 September 2019.

${ }^{4}$ Amy Steward, 'Flower Power' (2007) 161 Foreign Policy pp 44-52.
} 
thirds of exports are distributed via the Dutch auction. ${ }^{5}$ Despite the COVID-19 pandemic, the value of the floriculture sector increased with 3.3 per cent in 2020. ${ }^{6}$

The other EAC Partner States allowed Kenya to start the implementation of the agreement under the principle of variable geometry in June 2021.7 Afterwards, Kenya and the EU launched a strategic dialogue to strengthen their cooperation on a number of issues, including human rights. This article aims to identify two priorities for floriculture workers in this dialogue. It is structured as followed. Section 2 describes the trade relations between the EAC and the EU. Section 3 discusses the legal provisions that are relevant for the respect, protection and fulfilment of the human rights of floriculture workers in the EAC-EU EPA and the recently initialled post-Cotonou agreement. ${ }^{8}$ Section 4 identifies the following two priorities for these workers in the strategic dialogue between Kenya and the EU: sustained and continuous efforts towards Kenya's ratification of the International Labour Organisation's (ILO) Convention No. 87 on the Freedom of Association and Protection of the Right to Organise and the broadening of an enabling space for an active, organised and transparent civil society. ${ }^{9}$ This analysis relies upon a case study, including a literature review and interviews with fourteen experts in the field. ${ }^{10}$ Interviews have been conducted with lawyers and NGO,

${ }^{5}$ Winnie Mitullah, Paul Kamau and Joshua Kivuva, 'Employment Creation in Agriculture \& Agro-Processing Sector in Kenya in the Context of Inclusive Growth: Political Economy \& Settlement Analysis' (2017) Partnership for African Social \& Governance Research Working Paper Nr 20 <www.pasgr.org/wp-content/uploads/2017/08/Employmentcreation-in-agriculture-and-agro-processing-sector-in-Kenya-in-the-context-ofinclusive-growth.pdf $>$ accessed 28 February 2020 p 25.

${ }^{6}$ X, Study Reveals What Sustained Kenya's Economy in 2020' Further Africa (London, 15 July 2021) <https://furtherafrica.com/2021/07/15/study-reveals-what-sustained-kenyaseconomy-in-2020/> accessed 28 July 2021.

${ }^{7}$ EAC, 'Joint Communiqué: 21th Ordinary Summit of Heads of State of the East African Community' (2021) <www.eac.int/communique/1942-communiqué-of-the-21st-ordinarysummit-of-the-east-african-community-heads-of-state> accessed 11 May 2021.

8 Partnership Agreement Between [the European Union / The European Union and its Member States], of the one part, and Members of the Organisation of African, Caribbean and Pacific States, of the Other Part (2021) <https://ec.europa.eu/internationalpartnerships/system/files/negotiated-agreement-text-initialled-by-eu-oacps-chiefnegotiators-20210415_en.pdf > accessed 28 July 2021 (hereafter: post-Cotonou agreement).

${ }_{9}$ ILO Convention C087: Freedom of Association and Protection of the Right to Organise Convention (Convention concerning Freedom of Association and Protection of the Right to Organise) (31st ILC session San Francisco 9 July 1948).

${ }^{10}$ Cf Robert Yin, Case Study Research and Applications. Design and Methods (Sage 2018). 
trade union and government representatives in 2018 with the permission of the Kenya National Commission for Science, Technology \& Innovation. ${ }^{11}$

\section{Trade relations between EAC and EU}

Historically, the Kenyan floriculture sector benefited from policies promoted by economically developed states: the United States (US) and the EU. To begin, the US used international financial institutions to push its neoliberal agenda in the 1980s. Kenya was one of the first countries to sign a controversial structural adjustment loan with the World Bank. The lifting of air freight rates and other trade-liberalizing policies helped the Kenyan floriculture sector to blossom. ${ }^{12}$ In addition, this sector benefitted from the IVth Lomé Convention, an attempt by EU Member States to support and partner with their former colonies, the African, Caribbean and Pacific (ACP) group of states..$^{13}$ This system was, however, against the World Trade Organization's (WTO) Most Favoured Nation Principle, because preferential treatment granted to the ACP states should have been granted to other General Agreement on Tariffs and Trade States Parties with a similar level of development. ${ }^{14}$ In 2000, a new provision was included in the Cotonou Agreement, the overarching framework for EU relations with the ACP States, making it possible to negotiate different economic partnership agreements with regional groupings. ${ }^{15}$ Regionalism has sometimes been hailed as the nation-state's response to the excesses of neo-liberal globalisation. ${ }^{16}$ The EAC Partner States (Burundi, Kenya, Rwanda, Tanzania and Uganda) finalised the negotiations for an Economic Partnership Agreement with the EU in 2014. South Sudan - not a member of the WTO - became the sixth member of the EAC in 2016. The EAC-EU EPA is 'based on the principle of building on the acquis' of the Cotonou

11 The number of the research license is NACOSTI/P/18/59629/22158. This research also obtained approval from Cardiff University's School of Law and Politics Research Ethics Committee. The number of this approval is SREC/051217/07.

12 Geoffrey Gertz, 'Kenya's Trade Liberalization of the 1980s and 1990s: Policies, Impact, and Implications' (2010) Carnegie Endowment for International Peace Background Paper $<$ https://carnegieendowment.org/files/kenya_background.pdf $>$ accessed 26 May 2021 pp $10-11$.

${ }^{13}$ Fourth ACP-EEC Convention (signed 15 December 1989, entered into force 1 September 1991) The Courier Nr 120.

${ }_{14}$ Art I:1 General Agreement on Tariffs and Trade (adopted 15 April 1994, entered into force 1 January 1995) 1867 UNTS 154.

15 Partnership Agreement between the Members of the African, Caribbean and Pacific Group of States of the one part, and the European Community and its Member States of the other part (signed 22 June 2000, revised 25 June 2005 and 22 June 2010) OJ L 287 (hereafter: Cotonou Agreement).

16 Eg Wanyama Masinde and Christopher Otieno Omolo, 'The Road to East African Integration' in Emmanuel Ugirashebuja, John Eudes Ruhangisa, Tom Ottervanger and Armin Cuyvers (eds), East African Community Law (Brill 2017) p. 3. 
Agreement. ${ }^{17}$ The Cotonou agreement determines that human rights, democratic principles, and the rule of law are 'essential elements' that underpin the domestic and international policies of their partnership. ${ }^{18}$ A Party might take unilateral 'appropriate measures', including trade sanctions if the other Party does not comply with the essential elements. ${ }^{19}$ Such measures shall be proportionate to the failure to implement obligations under the agreement.

In April 2021, the EU and the Organisation of the African, Caribbean and Pacific Group of States (OACPS) initialled the post-Cotonou Agreement. In this agreement, the Parties recognise the importance of building on the achievements of the Cotonou agreement. ${ }^{20}$ They bear in mind the need for building on existing economic partnership agreements as instruments of their trade cooperation. ${ }^{21}$ According to Article 50(6) of the post-Cotonou agreement, references to appropriate measures in EPAs should be understood as references to the corresponding provision' in the post-Cotonou agreement. ${ }^{22}$

Article 139 EAC-EU EPA determines that this agreement enters into force when all EAC Partner States and EU Member States have signed and ratified. All EU Member States and Kenya have signed and ratified the agreement. However, the other EAC Partner States are reluctant to sign and ratify the agreement. Only Rwanda signed this agreement. The EAC Heads of State from this country, Burundi, Tanzania, Uganda and South Sudan postponed the endorsement of the EAC-EU EPA until 'satisfactory clarification of concerns'. ${ }^{23}$ There were calls to renegotiate the agreement with the EU, and there were reservations for Kenya to start implementing the agreement. This would weaken the strength of the EAC bloc and ambitions for more integration in the EAC. ${ }^{24}$

There are two reasons why the other EAC Partner States are less eager than Kenya to ratify the EAC-EU EPA. First, the other EAC Partner States all qualify as Least Developed Countries, which have duty-free and quota-free access to the EU

17 Art 4(a) EAC-EU EPA. See also Recital, arts 2, 75, 136 and 142(3) EAC-EU EPA.

18 Art 9(2) Cotonou agreement.

${ }^{19}$ Art 96 ibid.

20 Art 50(1) post-Cotonou agreement.

${ }^{21}$ Art 50(4) ibid.

22 The Post-Cotonou Agreement will become binding on the Parties under international law only after completion by each Party of its internal legal procedures necessary for the entry into force of the Agreement (or its provisional application).

${ }^{23}$ EAC, 'Joint Communiqué: 19th Ordinary Summit of Heads of State of the East African Community' (2019) <https://www.eac.int/communique/1001-joint-communiqu\%C3\%A919th-ordinary-summit-of-heads-of-state-of-the-east-african-community $>$ accessed 11 May 2021.

24 Aggrey Mutambo, 'East Africa: Kenya Moves to Implement Trade Deal with EU as Neighbours Lag' Daily Nation (Nairobi, 23 June 2021) $<$ https://nation.africa/kenya/news/kenya-moves-to-implement-trade-deal-with-eu-asneighbours-lag-3447546> accessed 28 July 2021. 
market under the Everything But Arms scheme. Second, the other EAC Partner States have relatively more reasons to be concerned about the impact of the EACEU EPA on their long-term objectives to promote industrialisation and to add value to their resources. The agreement provides for immediate duty-free and quota-free access to the EU market for all EAC exports, and gradual liberalisation of the EAC market to imports from the EU, providing access to 82.6 per cent of the market's value over 25 years. There are fears that East African companies will not be able to withstand heightened competition from EU corporations in East Africa. Article 44 of the post-Cotonou agreement stresses in this regard that the EU and the OACPS shall promote the transition from commodity dependence to diversified economies. Yet, imports from the EU into the EAC are currently dominated by machinery and mechanical appliances, equipment and parts, vehicles and pharmaceutical products, while the most important exports from the EAC to the EU are cut flowers, tea, coffee, tobacco, fish and vegetables. ${ }^{25}$ Compared to the other EAC Partner States, Kenya is relatively industrialized. Kenya's exports to the EU were 2.2 times as much as the exports of Tanzania, the most developed of the least developed EAC Partner States in 2020. ${ }^{26}$ Former President Mkapa furthermore accused the EU of using the agreement to secure access to East African raw materials. ${ }^{27}$ Indeed, other EU regulatory initiatives have been partly motivated by the willingness to secure the supply of raw materials from the EAC Partner States to the EU. ${ }^{28}$ For example, the Conflict Minerals Regulation aims to secure the supply of tin, tantalum, tungsten and gold from 'conflict-affected and high risk areas'. ${ }^{29}$ Burundi, Rwanda, South Sudan, Tanzania and Uganda are often counted amongst such areas. ${ }^{30}$ Such concerns are less pressing in Kenya because it

${ }^{25}$ European Commission, 'East African Community'

$<$ https://ec.europa.eu/trade/policy/countries-and-regions/regions/eac/> accessed 1

December 2020.

${ }^{26}$ See European Commission, 'European Union, Trade in Goods with Kenya' (2020) $<$ https://webgate.ec.europa.eu/isdb_results/factsheets/country/details_kenya_en.pdf> accessed 28 July 2021; European Commission, 'European Union, Trade in Goods with Tanzania'

$<$ https://webgate.ec.europa.eu/isdb_results/factsheets/country/details_tanzania_en.pdf> accessed 28 July 2021.

${ }^{27}$ Mkapa (n 1).

${ }^{28}$ Aleydis Nissen, "The European Union as a Manager of Global "Business and Human Rights" Regulation: Country-by Country Reporting Rules' (2019) 8(2) UCL Journal of Law \& Jurisprudence $\mathrm{p} 150$.

${ }^{29}$ European Parliament and Council, Regulation Nr 2017/821 Laying down Supply Chain Due Diligence Obligations for Union Importers of Tin, Tantalum and Tungsten, their Ores, and Gold Originating from Conflict-Affected and High Risk Areas' [2017] OJ L130/1.

${ }^{30}$ Eg Section 1502 US Dodd-Frank Wall Street Reform and Consumer Protection Ac 2010 (US); Phoebe Okowa, 'The Pitfalls of Unilateral Legislation in International Law: Lessons from Conflict Minerals Regulation (2020) 69 International and Comparative Law Quarterly p 705 . 
is resource-poor. There have only recently been discoveries of oil in the Kenyan region of Turkana County. ${ }^{31}$

Ultimately, at the 21th Ordinary Summit of Heads of State of the EAC in April 2021, it was concluded that those EAC Partner States that wish to start implementing the EAC-EU EPA can commence doing so under the principle of variable geometry. ${ }^{32}$ Article 7(1)(e) of the Treaty Establishing the EAC defines this principle. ${ }^{33}$ It is the principle of 'flexibility which allows for progression in co-operation among a sub-group of members in a larger integration scheme in a variety of areas and at different speeds'. Note that the interpretation of this provision by the Heads of State was rather broad; the letter of the law does not allow one single EAC Partner State to move ahead alone. ${ }^{34}$

\section{Obligations relevant for floriculture workers}

The green light given by the EAC Partner States seems to be good news for the Kenyan floriculture sector. This sector can continue exporting on an equal footing with its biggest competitors that are part of a free trade agreement with the EU (Colombia and Ecuador) or that qualify as Least Developed Countries under the Everything But Arms special arrangement (Ethiopia). Approximately 100,000 people are currently directly employed in the Kenyan floriculture sector. ${ }^{35}$ While the number of jobs in other industries in Kenya has stagnated, the number of floriculture jobs has doubled over the last decade. Many workers were put on unpaid leave between March and July 2020 when the farms were seeking solutions to deal with the movement and transport restrictions that were necessary to deal with the COVID-19 pandemic. ${ }^{36}$ But the sector has swiftly recovered afterwards. ${ }^{37}$

The EAC-EU EPA does, however, contain limited safeguards regarding the quality of these floriculture jobs. Article 3 EAC-EU EPA is a 'rendez-vous' clause. It provides that negotiations in, amongst others, areas of trade environment and sustainable development are left for future discussions that need to be take place within five years after the agreement has entered into force. One notable exception

${ }^{31}$ Kenya (Office of the Attorney General, Department of Justice) and Kenya National Commission on Human Rights, 'The National Action Plan on Business and Human Rights in Kenya. Report on the stakeholder Consultations held in Turkana County' (2017) $<$ http://nap.knchr.org/Portals/0/Reports/Turkana\%20regional\%20consultation\%20report. pdf?ver=2017-09-04-174649-783> accessed 28 February 2020 p 3.

${ }^{32} \mathrm{EAC}$ (n 7).

33 Treaty Establishing the East African Community (adopted 30 November 1999, entered into force 7 July 2000) 2144 UNTS 255.

${ }^{34}$ See also art 1 ibid.

${ }^{35}$ Whitehouse (n 3).

${ }^{36}$ Kenya (Central Bank), 'Monetary Policy Committee Flower Farms Survey' (2021) < www.centralbank.go.ke/uploads/market_perception_surveys/848246841_MPC\%20Surve y\%20of\%20Flower\%20Farms,\%20January\%202021.pdf> accessed 28 July 2021. 37 Ibid. 
is a provision that civil society should be represented in a consultative committee which may make communications at its own initiative or at the request of a Committee of Senior Officials. ${ }^{38}$

This is perhaps surprising. It is useful to highlight two issues that are relevant for floriculture workers. First, there are no safeguards regarding the right to health and safety at work in the EAC-EU EPA, while newspapers in the EU have been reporting on risks to occupational health and safety in the Kenyan floriculture industry since the 1990s. ${ }^{39}$ Floriculture workers are exposed to extreme temperatures in the greenhouses and cold rooms, and to a plethora of toxic chemicals, including those that are illegally imported. Second, no gender impact assessment has been carried out, while the EAC-EU EPA is likely to further contribute to the feminisation of precarious labour. The higher-paying jobs, such as supervision and construction, are disproportionally given to men in the floriculture sector. Women are concentrated in the more numerous lower-paying jobs, such as planting and picking. The gender factor cannot be isolated from a series of other factors. Many workers are single mothers who have migrated from non-flower growing regions to flower growing areas, such as the farms around Lake Naivasha. These internal migrants rely upon their employers for housing, transport, meals and medical assistance.

The post-Cotonou agreement between the EU and the OACPS, nevertheless, has the promotion, protection and fulfilment of human rights, democratic principles and the rule of law as central objectives and essential elements. ${ }^{40}$ Gender equality requires particular attention to achieve these objectives. This agreement explains that the Parties shall preserve and broaden an enabling space for an active, organised and transparent civil society. ${ }^{41}$ The Parties also agreed to promote the involvement of civil society and the private sector in dialogues to address trade and trade related issues of common interest. ${ }^{42}$ The Africa protocol to the post-Cotonou agreement notes in this regard that the Parties shall promote and facilitate dialogue between employers' and workers' organisations in the formal and informal economy and civil society organisations, including through capacity building. ${ }^{43}$ The Parties shall ensure an open and enabling space for individuals and civil society to voice their aspirations and concerns, express their opinions or make contributions to all political, economic,

\footnotetext{
${ }^{38}$ Art 108(1) EAC-EU EPA.

${ }^{39}$ Aleydis Nissen, 'In Kenia is de Ene Rozenplantage de Andere Niet: "Klagen is Ontslag Vragen"' Knack (Brussels, 24 October 2020) <https://www.knack.be/nieuws/wereld/inkenia-is-de-ene-rozenplantage-de-andere-niet-klagen-is-ontslag-vragen/article-longread1656597.html> accessed 24 October 2020.

${ }^{40}$ Art 1.3 and 9.6 post-Cotonou agreement. See also art 9 Cotonou agreement.

${ }^{41}$ Art 11(4) post-Cotonou agreement.

${ }^{42}$ Art 50(10) ibid.

${ }^{43}$ Art 35(6) Africa Protocol to ibid.
} 
social and cultural matters, contributing to increasing confidence in public institutions. ${ }^{44}$

Furthermore, the EU and the OACPS reaffirm their commitment to achieving full and productive employment and decent work for all women and men. ${ }^{45}$ While the Parties recognise their respective rights to determine sustainable development policy objectives and priorities and establish their own levels of domestic protection, they stipulate that it is inappropriate to encourage trade and investment by lowering or offering to lower the level of domestic protection afforded in labour and environmental laws, or their enforcement. ${ }^{46}$ The Parties agree to ensure respect for labour and social standards enshrined in the conventions and protocols of the ILO. They shall promote safe and secure working environments for all workers in line with the ILO framework. ${ }^{47}$ They commit, in particular, to social dialogue and to the promotion and effective implementation of the core labour standards. ${ }^{48}$ Article 33.2 of the post-Cotonou agreement even determines that the Parties 'shall' make 'sustained and continuous efforts' to ratify or accede to, as appropriate, conventions and protocols relating to core labour standards: the freedom of association and the effective recognition of the right to collective bargaining; the elimination of all forms of forced or compulsory labour; the effective abolition of child labour; and the elimination of discrimination in respect of employment and occupation. ${ }^{49}$ While it is not expressed that such efforts should be uninterrupted, this is considerably strong language. The Cotonou agreement simply stated that the ACP and the EU reaffirmed their commitment to the ILO core labour standards. ${ }^{50}$ The language used in the Post-Cotonou reflects the language that has been used in the EU's 'new generation' of free trade agreements since 2010. ${ }^{51}$ For example, Article 13.4.3 of the Free Trade Agreement between the Republic of Korea and the EU (2010) determines that the Parties agree to make continued and sustained efforts towards ratifying the fundamental ILO Conventions as well as the other conventions that are classified as 'up-to-date' by the ILO. ${ }^{52}$

${ }^{44}$ Art 64 post-Cotonou agreement.

${ }^{45}$ Arts 33.1 and 33.3 ibid. See also art 36 Africa Protocol to ibid.

${ }^{46}$ Art 49.2 and 49.3 post-Cotonou agreement.

${ }^{47}$ Arts 33.3 and 43.3 ibid. See also art 36.3, 36.4 and 41.3 Africa Protocol to ibid.

${ }^{48}$ Arts 33.2 post-Cotonou agreement.

${ }^{49}$ Ibid.

${ }^{50}$ Art 50 Cotonou agreement.

${ }^{51}$ Aleydis Nissen, 'Towards "More Assertive Enforcement" of Labour Obligations in EU FTAs' (working paper).

${ }^{52} \mathrm{Ibid}$; Free Trade Agreement between the European Union and its Member States, of the one part, and the Republic of Korea, of the other part (signed 6 October 2010, entered into force 13 December 2014) L127 p 6 (EU-Korea FTA). 


\section{Priorities}

In a joint statement published in June 2021, Kenya and the EU re-affirmed their commitment to democracy, the rule of law and human rights. ${ }^{53}$ They also committed to strengthen cooperation in these issues in their strategic dialogue. ${ }^{4}$ These efforts build upon recent Conclusions made by the Council of the EU that consider Kenya as a strategic partner in the Horn of Africa for various issues, including trade, investment and human rights because Kenya is considered to have strong potential for enhancing regional stability. ${ }^{55}$ As of July 2021, the EU has been reflecting internally on the modalities regarding the bilateral implementation of the Economic Partnership Agreement with Kenya. ${ }^{56}$ This section suggests two priorities for floriculture workers that should be taken into account in the strategic dialogue: sustained and continuous efforts towards Kenya's ratification of the ILO Convention No. 87 on the Freedom of Association and Protection of the Right to Organise and the broadening of an enabling space for an active, organised and transparent civil society. Such priorities build upon the commitments made in the post-Cotonou agreement that were explained in section 3 of this article.

Kenya's ratification of the core labour rights Convention No. 87 - the only core labour rights convention that it has not ratified - should be a priority in the strategic dialogue between the EU and Kenya. Frequent violations of the right to association occur in Kenya. Notoriously, Maina Kiai was reportedly detained at the airport of Nairobi by the immigration authorities before boarding a flight abroad in $2017 .{ }^{57} \mathrm{He}$ is the former UN Special Rapporteur on the Rights to Freedom of Peaceful Assembly and of Association and board member of the NGO Kenya Human Rights Commission (KHRC). The KHRC operates as a shadow national human rights institution that complies with the Paris Principles. ${ }^{58}$ This NGO interviewed 738 floriculture workers for its report "“Wilting in Bloom” The Irony

\footnotetext{
${ }^{53}$ Kenya and EU, 'Joint Statement to the Press' (2021) $<$ www.consilium.europa.eu/en/press/press-releases/2021/06/21/joint-statement-to-thepress-by-the-republic-of-kenya-and-the-european-union/> accessed 28 June 2021.

${ }^{54}$ Ibid.

${ }_{55}$ Council of the EU, 'The Horn of Africa: a Geo-Strategic Priority for the EU - Council Conclusions' (2021) 8135/2 para 34.

${ }^{56}$ European Commission, 'Overview of Economic Partnership Agreements. Updated in July 2021' $<$ https://trade.ec.europa.eu/doclib/docs/2009/september/tradoc_144912.pdf $>$ accessed 28 July 2021.

${ }^{57}$ Communication from Michel Frost, Special Rapporteur on the Situation of Human Rights Defenders, David Kaye, Special Rapporteur on the Promotion and Protection of the Right to Freedom of Opinion and Expression and Annalisa Ciampi, Special Rapporteur on the Rights to Freedom of Peaceful Assembly and Association to Kenya (25 August 2017) AL KEN 11/2017.

${ }^{58}$ UN General Assembly, Res 48/134 (1993) UN Doc A/48/49.
} 
of Women Labour Rights in the Cut Flower Sector in Kenya'. ${ }^{59}$ In this report, the KHRC describes instances of intimidation and discrimination against floriculture workers that join the Kenya Plantation and Agricultural Workers Union (KPAWU) ${ }^{60}$ The main effect is that unionised floriculture workers are deprived from collective bargaining opportunities. The report also describes that KPAWU's parent organization, the Central Organization of Trade Unions (COTU-K) suffers from undemocratic top-down governance structures and a general lack of accountability and transparency in the utilisation of union funds. ${ }^{61}$ KPAWU and its parent organization regularly violate the freedom of association and the right to organise. They use the legal system - including laws and court procedures - to do this. In the run-up of the 2007 presidential elections, COTU-K pressured then President Mwai Kibaki to adopt its proposed labour laws. ${ }^{62}$ It reportedly threatened to otherwise mobilise its large membership base to vote against him. Due to the time pressure, the laws were passed without broad stakeholder consultations. This allowed COTU-K to strengthen its monopoly position in Kenya. Notoriously, section 14(1)(d)(i) of the Labour Relations Act (2007) determines that a trade union may only apply for registration if no other trade union is already registered. KPAWU has continually been bringing lawsuits in court against the recognition of the Kenya Export Floriculture, Horticulture and Allied Workers Union (KEFHAU), which tried to register for the first time in 2009.63 In so doing, COTU-K and KPAWU deprive floriculture workers of the opportunity to join a union that is tailored to their needs, including specific protection of occupational health and safety and the rights of women workers. Violations of the right to organise are well-known to be correlated with weak protection of the right to safe and healthy work. ${ }^{64}$ Furthermore, COTU-K has a strong masculinist culture that often excludes women's voices and issues. ${ }^{65}$

${ }^{59}$ KHRC, “"Wilting in Bloom” The Irony of Women Labour Rights in the Cut Flower Sector in Kenya' (2012) <www.khrc.or.ke/publications/63-wilting-in-bloom-the-irony-ofwomen-s-labour-rights-in-the-cut-flower-sector-in-kenya/file.html > accessed 28 February 2020.

${ }^{60}$ Ibid p 9.

${ }^{61}$ Ibid $\mathrm{p} 31$.

${ }^{62}$ Aleydis Nissen, 'Kenyan Vulnerable Flower Workers' Access to Justice: a Case Study' (2021) 7(2) Labour \& Law Issues p C.32.

${ }^{63}$ KPAWU v David Benedict Omulama and others and the Registrar of Trade Unions (2017) 141/2014 Court of Appeal (Nairobi); KPAWU $v$ KEFHAU represented by David Benedict Omulama and others and the Registrar of Trade Unions (2018) 5/2017 Court of Appeal (Nairobi).

${ }^{64}$ HRC, 'Principles on Human Rights and the Protection of Workers from Exposure to Toxic Substances. Report of the Special Rapporteur on the Implications for Human Rights of the Environmentally Sound Management and Disposal of Hazardous Substances and Wastes' (2019) UN Doc A/HRC/42/41 Principle 10.

${ }^{65}$ Nissen (n 62) p C.33. 
Kenya has ratified the International Covenant on Economic Social and Cultural Rights, providing for the freedom of association and the enjoyment of just and favourable conditions of work, including safe and healthy working conditions as well as the International Covenant on Civil and Political Right, providing for the right of peaceful assembly and freedom of association. ${ }^{66}$ However, Kenya is not a party to the Optional Protocols to both Covenants. Accordingly, (groups of) individuals are not allowed to submit communications to the committees that monitor these Covenants to claim alleged violations of these obligations. However, complaints against Kenya can be filed by workers' organizations and employers' organizations to the ILO Committee on Freedom of Association. While Kenya has not ratified ILO Convention No. 87, the 1998 ILO Declaration on Fundamental Principles and Rights at Work commits Kenya - like all ILO Member States - to respect and promote core labour rights. Ratification of ILO Convention No. 87 remains important (as indicated by the post-Cotonou agreement). ${ }^{67}$ Even if Kenya would not be convinced that trade union rights are important, just paying lipservice to such rights can trigger important changes on the ground. Ciprian Radavoi and Yongmin Bian argue in this regard that purely symbolic adoption can start events that will - in the long run - lead to actual implementation. ${ }^{68}$ For such effect to take place, Thomas Risse and Kathryn Sikkink write that human rights need to be institutionalized in international and domestic law and that public naming and shaming need to be likely to occur when rights violations take place. ${ }^{69}$ The remainder of this section determines that human rights are increasingly institutionalised in Kenya, but that public naming and shaming has become increasingly difficult during Kenyatta's time in office.

Some flaws in the 2007 Labour Relations Act have been remedied by the 2010 Constitution. Women's organisations and other civil society organisations

${ }^{66}$ Arts 7 and 8 International Covenant on Economic, Social and Cultural Rights (adopted 16 December 1966, entered into force 3 January 1976) 993 UNTS 3 (ICESCR); Arts 21 and 22 International Covenant on Civil and Political Rights (adopted 16 December 1966, entered into force 23 March 1976) 999 UNTS 171 (ICCPR) (Note that the UN Human Rights Committee that monitors the ICCPR examines this article mostly in relation to political parties and NGOs).

${ }_{67}$ ILO, Declaration on Fundamental Principles and Rights at Work (86th Conference Session Geneva) (1998). See also ILO, Declaration on Social Justice for a Fair Globalization (97th Conference Session Geneva) (2008).

${ }^{68}$ Ciprian Radavoi and Yongmin Bian, Isomorphic Mutation and Strategic Adaptation in China's CSR Standards for Overseas Investors in Belén Díaz, Nicholas Capaldi, Samuel Idowu and René Schmidpeter (eds) Responsible Business in a Changing World (Springer 2020) p 264.

${ }^{69}$ Thomas Risse and Kathryn Sikkink, 'Conclusions' in Thomas Risse, Stephen Ropp and Kathryn Sikkink (eds), The Persistent Power of Human Rights: From Commitment to Compliance (Cambridge University Press 2013) p 284. Independent courts that can support rights claims are also important. For an analysis, see Nissen (n 62). 
succeeded to make their voices heard in this document to a considerable degree. ${ }^{70}$ The Constitution introduces a Bill of Rights that binds all State organs and all persons, including companies, associations and other bodies of persons. ${ }^{71}$ Furthermore, Article 2(1) of the Constitution determines that it takes precedence or supersedes any other law. In the absence of a specialised court to address constitutional matters, all Kenyan superior courts have the authority to make interpretations and determinations on the Constitution. Some judges have used this opportunity to determine that provisions in the Labour Relations Act are not in the letter and spirit of the Constitution..$^{72}$ Notably, an Industrial and Labour Relations Court relied upon the Bill of Rights to require the Registrar of Trade Unions to grant KEFHAU registration, noting that floriculture workers need specific protection. ${ }^{73}$ (At the time of writing, KEFHAU is not yet operational, as the Supreme Court has failed to call out the incompatibility of the single union requirements of section 14(1)(d)(i) Labour Relations Act with Article 24 of the Constitution and Kenya's international obligations, including article 8 ICESCR. ${ }^{74}$ )

Public naming and shaming remains, nevertheless, highly problematic. The relations between COTU-K and NGOs were already hostile when prominent figures in former President Daniel Arap Moi's Administration started investing in flower cultivation. ${ }^{75}$ COTU-K still portrays NGOs as self-serving groups that try to weaken the united voice of workers. While NGOs, of course, pursue their own agenda, COTU-K has consistently promoted the myth that labour rights are entirely distinct from human rights, and therefore, so the reasoning goes, its reserved domain. While there is some discussion regarding the relation between labour rights are human rights, it is widely recognised that the core labour rights

${ }^{70}$ Nkatha Kabira, 'Constitutionalizing Traveling Feminisms in Kenya' (2019) 52 Cornell International Law Journal.

${ }^{71}$ Art 20 Constitution (2010).

72 See Kenya (National Council for Law Reporting), 'Legislation / Provisions of the Law Declared Unconstitutional' <www.kenyalaw.org/kl/index.php?id=8662> accessed 28 February 2020.

${ }^{73}$ David Benedict Omulama and others $v$ the Registrar of Trade Unions (2014) 7/2011 Industrial Court (Nairobi). See also KPAWU v David Benedict Omulama and others (2017) 141/2014 Court of Appeal (Nairobi).

${ }^{74}$ KPAWU v KEFHAU and the Registrar of Trade Unions (2020) 4/2018 Supreme Court. See KEFHAU v KPAWU et al. (2021) e6451/2020 Employment and Labour Relations Court (Nakuru).

${ }^{75}$ Eric Otenyo, 'Politics and the Lack of Labor Militancy in Kenya: Trade Unionism after Independence' in Michael Mwenda Kithinji, Mickie Mwanzia Moster and Jerono Rotich (eds), Kenya After 50 (Palgrave Macmillan 2016) pp 115 and 122. 
are human rights. ${ }^{76}$ In Kenya, however, various NGO representatives believe that these are entirely separate concepts.

In addition, the space for civil society has been shrinking since Uhuru Kenyatta took office in 2013. A National Steering Committee was set up through a multi-stakeholder forum to develop a National Action Plan on Business and Human Rights in 2016, but only a limited range of civil society organisations had been consulted. ${ }^{77}$ The government has also actively tried to weaken the impact of the Public Benefits Organizations Act (2013). ${ }^{78}$ Among other things, this Act places the regulation of NGOs and civil society organizations under the authority of the Ministry of Planning and Devolution, responsible for supporting the 47 county governments through policy formulation, capacity support and intergovernmental relations. According to the Constitution, the governments at the national and county levels are distinct but interdependent. ${ }^{79}$ They must conduct their mutual relations on the basis of consultation and cooperation. However, the NGO Co-ordination Board, a central agency working under the authority of the Ministry of Interior and Coordination, has remained in charge. ${ }^{80}$ In 2015, this Board announced its intention to cancel the registration of 957 NGOs, including the KHRC. ${ }^{81}$ In 2017, there have been new allegations of intimidation of KHRC. Three UN Special Rapporteurs linked this to the fact that KHRC had questioned the credibility of Kenyatta's re-election. Competition for public office and a considerable degree of participation by citizens in electing governments are important elements to ensure that democratic principles and human rights are respected, promoted and fulfilled. ${ }^{82}$ The Board reportedly advised the Central Bank of Kenya to freeze the KHRC's assets and to 'deport all foreigners'.

${ }^{76}$ Janice Bellace and Beryl ter Haar, 'Perspectives on Labour and Human Rights' in Janice Bellace and Beryl ter Haar (eds), Research Handbook on Labour, Business and Human Rights Law (Routledge 2019) p 3.

${ }^{77}$ Kenya (Government), 'NAP' (2019); UN Working Group on Business and Human Rights, 'Statement at the End of Visit to Kenya' (2018) $<$ www.ohchr.org/EN/NewsEvents/Pages/DisplayNews.aspx?NewsID=23356\&LangID=E> accessed 1 December 2018.

${ }_{78} \mathrm{OHCHR}$, ‘UN Experts Urge Kenya to End Crackdown on Rights Groups to Ensure Fair Elections'

$<$ www.ohchr.org/EN/NewsEvents/Pages/DisplayNews.aspx?NewsID=21172\&LangID=E $>$ accessed 30 September 2019.

79 Art 6(2) and 189(1) Constitution (2010); Faith Simiyu, 'Demystifying the Quest for Develoved Governance of Agriculture in Kenya' (2015) Jomo Kenyatta University of Agriculture and Technology Law Journal p 5.

${ }^{80}$ AL KEN 11/2017 (n 57).

${ }^{81}$ Communication from David Kaye, Special Rapporteur on the Promotion and Protection of the Right to Freedom of Opinion and Expression, Maini Kiai, Special Rapporteur on the Rights to Freedom of Peaceful Assembly and Association and Special Rapporteur on the Situation of Human Rights Defenders to Kenya (6 February 2017) AL KEN 3/2017.

${ }^{82} \mathrm{Cf}$ art 64 post-Cotonou agreement; Risse and Sikkink (n 69) p 287. 
Designating civil society organisations as 'foreign agents' is a well-known tactic to stifle its workings. ${ }^{83}$

In order to start a meaningful strategic dialogue about human rights with Kenya, the EU should definitely take up these accusations of intimidation of civil society. It has been explained in section 3 above that the Post-Cotonou agreement provides a legal basis to do this. It is also important to stress that the EU should not abuse the bilateral relations to push the interests of business people from the EU in Kenya. This has happened in the past. Together with the Kenyan elite and Indian business people, European business people own the approximately 190 larger flower farms in Kenya. ${ }^{84}$ In response to the allegations regarding human rights violations in the floriculture sector in the 1990s, they have certified their flowers with development aid funded by individual EU Member States. ${ }^{85}$ This development might seem to be a success story, but it emerged from the interviews that it has created two considerable challenges on the ground. First, voluntary standards are reportedly used as an excuse to not create comprehensive mandatory regulation to protect agriculture workers. Second, these standards have created considerable barriers for the approximately 2,500 Kenyan smallholders who have difficulties to understand ethical consumer demands in the EU.

\section{Conclusion}

While the other EAC Partner States remain reluctant to ratify the EAC-EU EPA, they allowed Kenya to start its implementation under the principle of variable geometry in June 2021. Article 3 EAC-EU EPA planned a 'rendez-vous' for the Parties to discuss human rights. In their strategic dialogue, Kenya and the EU referred to cooperation on human rights issues. This article explained that Kenya and the EU need to be careful not to subordinate the perceived interests of floriculture workers to people with economic and political capital. This article identified Kenya's ratification of core labour rights Convention No. 87 on Freedom of Association and Protection of the Right to Organise as a priority. Article 33.2 of the post-Cotonou agreement - that has been initialled in April 2021 - determines

${ }^{83}$ David Birchall, 'The Role of Civil Society and Human Rights Defenders in Corporate Accountability' in Surya Deva and David Birchall (eds), The Edward Elgar Research Handbook on Human Rights and Business (Edward Elgar 2020) p 440.

${ }^{84}$ Agnieszka Kazimierczuk, Paul Kamau, Bethuel Kinuthia and Catherine Mukoko, 'Never a Rose without a Prick: (Dutch) Multinational Companies and Productive Employment in the Kenyan Flower Sector' (2018) ASC Working Paper Nr 142 $<$ https://openaccess.leidenuniv.nl/bitstream/handle/1887/64705/Working_paper_142.pdf? sequence $=1>$ accessed 20 December 2018 p 18.

${ }^{85}$ Alex Hughes, 'Global Commodity Networks, Ethical Trade and Governmentality: Organising Business Responsibility in the Kenyan Cut Flower Industry' (2001) 26(4) Transactions of the Institute of British Geographers p 395. 
in this regard that the Parties 'shall' make 'sustained and continuous efforts' to ratify or accede to, as appropriate, conventions and protocols relating to core labour standards. Even if Kenya would not be convinced that trade union rights are important, paying lip-service to such rights can limit the outsized influence of the centralised trade union COTU-K. For such effect to take place, it will be important that active, organised and transparent civil society organisations can voice their aspirations and concerns. This is another priority area of cooperation that the EU and Kenya need to explore. One important issue will be to broaden the space for civil society to monitor Kenya's next general election in August 2022.

\section{Bibliography}

Janice Bellace and Beryl ter Haar, 'Perspectives on Labour and Human Rights' in Janice Bellace and Beryl ter Haar (eds), Research Handbook on Labour, Business and Human Rights Law (Routledge 2019).

David Birchall, 'The Role of Civil Society and Human Rights Defenders in Corporate Accountability' in Surya Deva and David Birchall (eds), The Edward Elgar Research Handbook on Human Rights and Business (Edward Elgar 2020).

Council of the EU, 'The Horn of Africa: a Geo-Strategic Priority for the EU Council Conclusions' (2021) 8135/2.

EAC, 'Joint Communiqué: 19th Ordinary Summit of Heads of State of the East African Community' (2019) <https://www.eac.int/communique/1001-jointcommuniqu\%C3\%A9-19th-ordinary-summit-of-heads-of-state-of-the-eastafrican-community> accessed 11 May 2021.

EAC, 'Joint Communiqué: 21th Ordinary Summit of Heads of State of the East African Community' (2021) <www.eac.int/communique/1942-communiqué-ofthe-21st-ordinary-summit-of-the-east-african-community-heads-of-state> accessed 11 May 2021.

European Commission, 'East African Community' $<$ https://ec.europa.eu/trade/policy/countries-and-regions/regions/eac/> accessed 1 December 2020.

European Commission, 'European Union, Trade in Goods with Kenya' (2020) $<$ https://webgate.ec.europa.eu/isdb_results/factsheets/country/details_kenya_en. pdf $>$ accessed 28 July 2021. 
European Commission, 'European Union, Trade in Goods with Tanzania' (2020) $<$ https://webgate.ec.europa.eu/isdb_results/factsheets/country/details_tanzania_e n.pdf $>$ accessed 28 July 2021.

European Commission, 'Overview of Economic Partnership Agreements. Updated in July 2021'

<https://trade.ec.europa.eu/doclib/docs/2009/september/tradoc_144912.pdf> accessed 28 July 2021.

Michel Frost, Special Rapporteur on the Situation of Human Rights Defenders, David Kaye, Special Rapporteur on the Promotion and Protection of the Right to Freedom of Opinion and Expression and Annalisa Ciampi, Special Rapporteur on the Rights to Freedom of Peaceful Assembly and Association to Kenya (25 August 2017) Communication AL KEN 11/2017.

Geoffrey Gertz, 'Kenya's Trade Liberalization of the 1980s and 1990s: Policies, Impact, and Implications' (2010) Carnegie Endowment for International Peace Background Paper

$<$ https://carnegieendowment.org/files/kenya_background.pdf $>$ accessed 26 May 2021.

Alex Hughes, 'Global Commodity Networks, Ethical Trade and Governmentality: Organising Business Responsibility in the Kenyan Cut Flower Industry' (2001) 26(4) Transactions of the Institute of British Geographers.

HRC, ‘Principles on Human Rights and the Protection of Workers from Exposure to Toxic Substances. Report of the Special Rapporteur on the Implications for Human Rights of the Environmentally Sound Management and Disposal of Hazardous Substances and Wastes' (2019) UN Doc A/HRC/42/41.

Nkatha Kabira, 'Constitutionalizing Traveling Feminisms in Kenya' (2019) 52 Cornell International Law Journal.

David Kaye, Special Rapporteur on the Promotion and Protection of the Right to Freedom of Opinion and Expression, Maini Kiai, Special Rapporteur on the Rights to Freedom of Peaceful Assembly and Association and Special Rapporteur on the Situation of Human Rights Defenders to Kenya (6 February 2017) Communication AL KEN 3/2017.

Agnieszka Kazimierczuk, Paul Kamau, Bethuel Kinuthia and Catherine Mukoko, 'Never a Rose without a Prick: (Dutch) Multinational Companies and Productive Employment in the Kenyan Flower Sector' (2018) ASC Working Paper Nr 142 
$<$ https://openaccess.leidenuniv.nl/bitstream/handle/1887/64705/Working_paper_1 42.pdf?sequence=1> accessed 20 December 2018.

Kenya (Central Bank), 'Monetary Policy Committee Flower Farms Survey' (2021) $<$ www.centralbank.go.ke/uploads/market_perception_surveys/848246841_MPC\% 20Survey\%20of\%20Flower\%20Farms,\%20January\%202021.pdf> accessed 28 July 2021.

Kenya (Government), 'NAP' (2019); UN Working Group on Business and Human Rights, 'Statement at the End of Visit to Kenya' (2018) $<$ www.ohchr.org/EN/NewsEvents/Pages/DisplayNews.aspx?NewsID=23356\&La ngID=E $>$ accessed 1 December 2018.

Kenya (National Council for Law Reporting), 'Legislation / Provisions of the Law Declared Unconstitutional' <www.kenyalaw.org/kl/index.php?id=8662> accessed 28 February 2020.

Kenya (Office of the Attorney General, Department of Justice) and Kenya National Commission on Human Rights, 'The National Action Plan on Business and Human Rights in Kenya. Report on the stakeholder Consultations held in Turkana County' <http://nap.knchr.org/Portals/0/Reports/Turkana\%20regional\%20consultation\%2 Oreport.pdf?ver=2017-09-04-174649-783> accessed 28 February 2020.

Kenya and EU, 'Joint Statement to the Press' $<$ www.consilium.europa.eu/en/press/press-releases/2021/06/21/joint-statementto-the-press-by-the-republic-of-kenya-and-the-european-union/> accessed 28 June 2021.

KHRC, "Wilting in Bloom" The Irony of Women Labour Rights in the Cut Flower Sector in Kenya' (2012) <www.khrc.or.ke/publications/63-wilting-in-bloom-theirony-of-women-s-labour-rights-in-the-cut-flower-sector-in-kenya/file.html> accessed 28 February 2020.

Wanyama Masinde and Christopher Otieno Omolo, 'The Road to East African Integration' in Emmanuel Ugirashebuja, John Eudes Ruhangisa, Tom Ottervanger and Armin Cuyvers (eds), East African Community Law (Brill 2017).

Winnie Mitullah, Paul Kamau and Joshua Kivuva, 'Employment Creation in Agriculture \& Agro-Processing Sector in Kenya in the Context of Inclusive Growth: Political Economy \& Settlement Analysis' (2017) Partnership for African Social \& Governance Research Working Paper Nr $20<w w w . p a s g r . o r g / w p-$ content/uploads/2017/08/Employment-creation-in-agriculture-and-agro- 
processing-sector-in-Kenya-in-the-context-of-inclusive-growth.pdf $>$ accessed 28 February 2020.

Benjamin William Mkapa, 'Why the EPA is not Beneficial to Tanzania' (The South Bulletin, 1 November 2016) <www.southcentre.int/question/why-the-epa-is-notbeneficial-to-tanzania/> accessed 28 February 2020.

Aggrey Mutambo, 'East Africa: Kenya Moves to Implement Trade Deal with EU as Neighbours Lag' Daily Nation (Nairobi, 23 June 2021) $<$ https://nation.africa/kenya/news/kenya-moves-to-implement-trade-deal-witheu-as-neighbours-lag-3447546> accessed 28 July 2021.

Aleydis Nissen, 'The European Union as a Manager of Global "Business and Human Rights" Regulation: Country-by Country Reporting Rules' (2019) 8(2) UCL Journal of Law \& Jurisprudence.

Aleydis Nissen, 'In Kenia is de Ene Rozenplantage de Andere Niet: "Klagen is Ontslag Vragen"' Knack (Brussels, 24 October 2020) < https://www.knack.be/nieuws/wereld/in-kenia-is-de-ene-rozenplantage-deandere-niet-klagen-is-ontslag-vragen/article-longread-1656597.html> accessed 24 October 2020.

Aleydis Nissen, 'Kenyan Vulnerable Flower Workers' Access to Justice: a Case Study' (2021) 7(2) Labour \& Law Issues.

Aleydis Nissen, “Towards “More Assertive Enforcement" of Labour Obligations in EU FTAs' (working paper).

OHCHR, 'UN Experts Urge Kenya to End Crackdown on Rights Groups to Ensure Fair Elections'

$<$ www.ohchr.org/EN/NewsEvents/Pages/DisplayNews.aspx?NewsID=21172\&La ngID=E $>$ accessed 30 September 2019.

Phoebe Okowa, 'The Pitfalls of Unilateral Legislation in International Law: Lessons from Conflict Minerals Regulation (2020) 69 International and Comparative Law Quarterly.

Eric Otenyo, 'Politics and the Lack of Labor Militancy in Kenya: Trade Unionism after Independence' in Michael Mwenda Kithinji, Mickie Mwanzia Moster and Jerono Rotich (eds), Kenya After 50 (Palgrave Macmillan 2016).

Eric Pichon, 'Briefing. International Agreements in Progress. Economic Partnership Agreement with the East African Community' (2018) 
<www.europarl.europa.eu/RegData/etudes/BRIE/2018/620218/EPRS_BRI(2018)62 0218_EN.pdf $>$ accessed 28 February 2020.

Ciprian Radavoi and Yongmin Bian, Isomorphic Mutation and Strategic Adaptation in China's CSR Standards for Overseas Investors in Belén Díaz, Nicholas Capaldi, Samuel Idowu and René Schmidpeter (eds) Responsible Business in a Changing World (Springer 2020).

Thomas Risse and Kathryn Sikkink, 'Conclusions' in Thomas Risse, Stephen Ropp and Kathryn Sikkink (eds), The Persistent Power of Human Rights: From Commitment to Compliance (Cambridge University Press 2013).

Faith Simiyu, 'Demystifying the Quest for Develoved Governance of Agriculture in Kenya' (2015) Jomo Kenyatta University of Agriculture and Technology Law Journal.

Amy Steward, 'Flower Power' (2007) 161 Foreign Policy.

UN General Assembly, Res 48/134 (1993) UN Doc A/48/49.

David Whitehouse, 'Kenya's Flower Growers to Share Brexit Pain' The Africa Report (Paris, 17 April 2019) <www.theafricareport.com/11976/kenyas-flowergrowers-to-share-brexit-pain/> accessed 20 September 2019.

X, Study Reveals What Sustained Kenya's Economy in 2020' Further Africa (London, 15 July 2021) <https://furtherafrica.com/2021/07/15/study-reveals-whatsustained-kenyas-economy-in-2020/> accessed 28 July 2021.

Robert Yin, Case Study Research and Applications. Design and Methods (Sage 2018). 